\title{
C-Peptide and 24-Hour Urinary C-Peptide as Markers to Help Classify Types of Childhood Diabetes
}

\author{
Lorraine E. Levitt Katz \\ Division of Endocrinology and Diabetes, The Children's Hospital of Philadelphia, Perelman School of Medicine, \\ University of Pennsylvania, Philadelphia, Pa., USA
}

The prevalence of different types of diabetes varies widely among regions, countries and populations $[1,2]$. Determining the correct type of diabetes during childhood is important to decide the optimal treatment and follow-up care as well as risk factors for families. Historically, children presenting with new diabetes were presumed to have type 1 diabetes (T1DM), originally called juvenile diabetes. Improved classification of diabetes in youth has presented clinicians with diagnostic challenges when evaluating patients. The presence of obesity and acanthosis nigricans is suggestive of type 2 diabetes (T2DM). However, given the rising prevalence of obesity in children, obesity alone does not exclude other types of diabetes. The clinical presentation of children with diabetes may range from mild hyperglycemia to ketoacidosis. Atypical diabetes in African-American children presenting with severe insulin deficiency with a subsequent noninsulin-dependent course has been recognized for several decades $[3,4]$. Presently, apart from genetic testing, diagnostic criteria do not always distinguish children with T1DM from maturity-onset diabetes of youth (MODY) or from T2DM.

MODY, which represents a small percent of diabetes cases [5], is often misdiagnosed as T1DM or T2DM. It has recently been determined that MODY is not uncommon in youth with diabetes [6]. Classic MODY was originally described in Caucasians as autosomally inherited with (c) 2015 S. Karger AG, Basel

$1663-2818 / 15 / 0841-0062 \$ 39.50 / 0$ preserved beta-cell function and negative autoantibodies [7]. While a family history of diabetes is rare in youth with T1DM, individuals with MODY and standard T2DM will show a strong family history of T2DM.

There are demographic differences in the types of childhood diabetes. Although the incidence of T1DM is higher in white children, the incidence is increasing in black children [8], and the incidence in Hispanic children of Puerto Rican origin is among the highest in the US [9, 10]. In T2DM, more minority children are affected, with prevalence rates in African-Americans, Mexican Americans, and Native Americans higher than those of Caucasians. The onset of T2DM is common during puberty and may be related to the decline in insulin sensitivity during this period of development $[11,12]$.

The SEARCH for Diabetes in Youth study [13] has helped to shed further light on the demographic characteristics of American youth diagnosed with MODY. In SEARCH, autoantibody-negative subjects with fasting C-peptide levels $>0.8 \mathrm{mg} / \mathrm{ml}$ underwent sequencing for MODY mutations. Out of 47 participants, $8 \%$ of those tested were found to have a MODY gene mutation. Most of these subjects had been on insulin, and only 3 had a prior diagnosis of MODY [14]. Unlike the classic description of MODY, only half of the participants had a family history of diabetes, and 64\% of the SEARCH MODY patients were of a minority ethnicity.

\section{KARGER 125}

E-Mail karger@karger.com

www.karger.com/hrp
Lorraine E. Levitt Katz, Division of Endocrinology and Diabetes

The Children's Hospital of Philadelphia, Perelman School of Medicine, University of Pennsylvania, South Tower, 8th floor, Room 8C09

34th Street and Civic Center Blvd., Philadelphia, PA 19104-4399 (USA)

E-Mail katzl@email.chop.edu 
While positivity for islet cell antibodies supports the diagnosis of T1DM [15], the presence of autoantibodies does not rule out MODY or T2DM. A proportion of adults with T2DM may have autoimmune markers, and this finding is often associated with progressive beta-cell failure [16-19]. There is also overlap in diabetes type in pediatrics, as obese youth with features of T2DM may have positive autoantibodies [20]. Not all children with T1DM are positive for diabetes antibodies, and even those with genetic MODY may have elevated antibody titers [21].

As described above, individual characteristics are not discriminatory for diabetes type. Improved diagnosis of diabetes type provides the opportunity for determination of the genetic risk in families as well as prevention trials. A clear diagnosis improves treatment determinations, particularly in MODY, which is frequently misdiagnosed. For example, individuals with HNF1A and HNF4A MODY respond to sulfonylureas, whereas those with glucokinase mutations typically do not need therapy, other than during pregnancy. Misdiagnosis of diabetes type may have an impact on cost and quality of life. Genetic tests are required to definitively diagnose MODY, and these tests are expensive and cannot always be performed. Consequently, new clinical and laboratory markers may be used to support the diagnosis of MODY.

C-peptide has been utilized in the typology of childhood diabetes. Our research group has shown that a fasting C-peptide level of $0.85 \mathrm{ng} / \mathrm{ml}$ at diagnosis can differentiate T1DM from T2DM with a sensitivity of $83 \%$ and a specificity of $89 \%$ [22]. C-peptide measurement may also help in differentiating T1DM from MODY [23]. Cpeptide can be measured after stimulation by a mixed meal or during fasting, with a good correlation with each other [24-26]. Fasting C-peptide is obtained more easily during clinical visits, and the levels also correlate with urinary C-peptide measures. In T1DM, residual insulin secretion is commonly seen only during the first 2 years after diagnosis, but rarely after 5 years [27]. C-peptide levels at this time are low, while in T2D and in MODY, C-peptide may be conserved for a longer duration.

The urinary C-peptide creatinine ratio (UCPCR) is a new marker for endogenous insulin secretion. The UCPCR provides another measure for beta-cell function in clinical practice [28]. In the Study by Yilmaz Agladioglu et al. [29], the use of the UCPCR and fasting C-peptide levels was investigated in the differential diagnosis between MODY and T1DM. T1DM subjects received insulin treatment and had been diagnosed with diabetes for at least 2 years. C-peptide measurements were performed af-

Markers to Classify Types of Childhood Diabetes ter an overnight fast, on the same day as the UCPCR test. Fasting C-peptide in the T1DM group was lower than that in the MODY group, with a fasting C-peptide cutoff point determined by ROC curve analysis to be $0.62 \mathrm{ng} / \mathrm{ml}$. This cutoff had a sensitivity of $93 \%$ and a specificity of $90 \%$ for discriminating between MODY and T1DM. UCPCR $\geq 0.22 \mathrm{nmol} / \mathrm{mmol}$ yielded a $96.3 \%$ sensitivity and a $85.7 \%$ specificity for MODY. The authors conclude that UCPCR and fasting C-peptide levels in children and adolescents can distinguish patients with MODY from patients with T1DM with a high specificity and sensitivity.

Accurately diagnosing the type of diabetes is crucial for appropriate treatment. This study and others suggest that C-peptide measurements combined with measurement of the UCPCR may provide an estimate of beta-cell function in children. This is the first pediatric report to utilize both the UCPCR and fasting C-peptide in patients with MODY and T1DM. UCPCR levels $\geq 0.22 \mathrm{nmol} /$ mmol showed a good discrimination between MODY and T1DM in children and are similar to those in the paper by Besser et al. [28] reporting that a UCPCR $>0.2$ $\mathrm{nmol} / \mathrm{mmol}$ could differentiate between MODY and T1DM with disease durations longer than 5 years. UCPCR testing is most useful in patients with a longer duration of diabetes, in keeping with a gradual loss of C-peptide [30]. A prior pediatric study reported that a UCPCR $\geq 0.7 \mathrm{nmol} / \mathrm{mmol}$ effectively discriminates between T1DM and non-T1DM (T2DM and MODY), with a sensitivity of $100 \%$ and a specificity of $81 \%$, independent of diabetes duration [31]. In the current study, although all patients with T1DM had a duration of diabetes longer than 2 years, a UCPCR level $\geq 0.7 \mathrm{nmol} / \mathrm{mmol}$ was less sensitive for diagnosis. MODY patients may have been missed if a UCPCR level $\geq 0.7 \mathrm{nmol} / \mathrm{mmol}$ was used for children more than 2 years from diagnosis. Curiously, in both the T1DM and MODY groups, there was a negative correlation between the duration of diabetes and the UCPCR. In the T1DM group, the duration of diabetes in 21 patients was $2-5$ years, and the duration in the other 21 cases was longer than 5 years.

Clinical findings in types of diabetes overlap and challenge the typology of childhood diabetes, blurring distinctions that previously guided diagnosis. Biochemical markers of C-peptide and 24-hour urinary C-peptide add to the understanding of markers of diagnosis consistent with current theories of the pathogenesis of diabetes. The paper by Yllmaz Agladioglu et al. [29] suggests that UCPCR and fasting C-peptide testing after 2 years of diagnosis in children and adolescents is able to distinguish patients with MODY from patients with T1DM with a 
high specificity and sensitivity. Further studies in larger samples with a wider distribution of patients with specific MODY mutations are indicated. However, the current findings point out that a UCPCR $\geq 0.22 \mathrm{nmol} / \mathrm{mmol}$ may indicate the need for performing a genetic test for
MODY. The combination of physical features, demographic characteristics and autoimmunity help distinguish T1DM, T2DM and MODY, and the use of these additional markers of beta-cell function may aid further in the diagnostic paradigm.

\section{References}

1 LaPorte RE, Tajima N, Akerblom HK, et al: Geographic differences in the risk of insulindependent diabetes mellitus: the importance of registries. Diabetes Care 1985;8(Suppl 1):101-107.

-2 Dabelea D, Mayer-Davisa EJ, Saydah S, et al: Prevalence of type 1 and type 2 diabetes among children and adolescents from 2001 to 2009. JAMA 2014;311:1778-1786.

-3 Umpierrez GE, Casals MMC, Gebhart SSP, Mixon PS, Clark WS, Phillips LS: Diabetic ketoacidosis in obese African-Americans. Diabetes 1995;44:790-795.

4 Winter WE, Maclaren NK, Riley WJ, Clarke DW, Kappy MS, Spillar RP. Maturity - onset diabetes of youth in black Americans. N Engl J Med 1987;316:285-291.

5 Neu A, Feldhahn L, Ehehalt S, Hub R, Ranke MB: Type 2 Diabetes mellitus in children and adolescents is still a rare disease in Germany: a population-based assessment of the prevalence of type 2 diabetes and MODY in patients aged 0-20 years. Pediatric Diabetes 2009:10: 468-473.

6 Ledermann HM: Is maturity onset diabetes at young age (MODY) more common in Europe than previously assumed? Lancet $1995 ; 345$ : 648.

7 Fajans SS, Bell GI, Polonsky KS: Molecular mechanisms and clinical pathophysiology of maturity-onset diabetes of the young. $\mathrm{N} \mathrm{Engl}$ J Med 2001;345:971-980.

8 Lipton RB, Drum M, Li S, Choi H: Social environment and year of birth influence of type 1 diabetes risk for African-American and Latino children. Diabetes Care 1999;22 $78-85$.

$\checkmark 9$ Lipman TH: The epidemiology of type 1 diabetes in children 0-14 years of age in Philadelphia. Diabetes Care 1993;16:922-925.

10 Lipman TM, Jawad A, Murph KM, Tuttle A, Thompson RL, Ratcliffe SJ, Katz L: Incidence of type 1 diabetes in Philadelphia is higher in black than white children from 1995 to 1999: epidemic or misclassification? Diabetes Care 2006;29:2391-2395.

-11 Amiel SA, Shermin RS, Simonson DC, lauritano AA, Tamborlane WV: Impaired insulin action in puberty: a contributing factor to poor glycemic control in adolescents with diabetes. N Engl J Med 1986;315:215-219.

$\$ 12$ Arslanian SA, Kalhan SC: Correlations between fatty acid and glucose metabolism: potential explanation of insulin resistance at puberty. Diabetes 1994;43:908-914.
13 Writing Group for the SEARCH for Diabetes in Youth Study Group: Incidence of diabetes in youth in the United States. JAMA 2007; 297:2716-2724.

14 Pihoker C, Gilliam LK, Ellard S, et al: Prevalence, characteristics and clinical diagnosis of maturity onset diabetes of the young due to mutations in HNF1, HNF4A, and glucokinase: results from the SEARCH for Diabetes in Youth. J Clin Endocrinol Metab 2013;98: 4055-4062.

15 Libman UM, Pietropaolo M, Trucco M, Dorman JS, LaPorte RE, Becker DJ: Islet cell autoimmunity in white and black children and adolescents with T1DM. Diabetes Care 1998; 21:1824-1827.

16 Turner R, Stratton I, Horton V, Manley S, Zimmet P, Mackay IR, Shattock M, Bottazo GF, Holman R: UKPDS 25: autoantibodies to islet-cell cytoplasm and glutamic acid decarboxylase for prediction of insulin requirement in type 2 diabetes. UK Propective Diabetes Study Group. Lancet 1997;350:1288-1293.

17 Brooks-Worrell, BB, Narla R, Palmer J: Islet autoimmunity in phenotypic type 2 diabetes patients. Diabetes Obes Metab 2013;15(Suppl 3):137-140.

18 Niskanen L, Karjalainen J, Sarlund H, et al: Five-year follow-up of islet-cell antibodies in type 2 (non-insulin-dependent) diabetes mellitus. Diabetologia 1991;34:401-408.

19 Tuomi T, Carlsson A, Li H, et al: Clinical and genetic characteristics of type 2 diabetes with and without GAD antibodies. Diabetes 1999; 48:150-157.

20 Klingensmith GJ, Pyle L, Arslanian S, et al: The presence of GAD and IA-2 Antibodies in youth with a type 2 diabetes phenotype: results from the TODAY study. Diabetes Care 2010;33:1970-1975.

21 Schober E, Rami B, Grabert M, et al: Phenotypical aspects of maturity-onset diabetes of the young (MODY diabetes) in comparison with type 2 diabetes mellitus (T2DM) in children and adolescents: experience from a large multicenter database. Diabet Med 2009;26: 466-473.

22 Katz LE, Jawad AF, Ganesh J, Abraham M, Murphy K, Lipman TH: Fasting C-peptide and insulin-like growth factor-binding protein-1 levels help to distinguish childhood type 1 and type 2 diabetes at diagnosis. Pediatr Diabetes 2007:8:53-59.

23 Hattersley A, Bruining J, Shield J, Njolstad P, Donaghue K; International Society for Pedi- atric and Adolescent Diabetes: ISPAD Clinical Practice Consensus Guidelines 20062007. The diagnosis and management of monogenic diabetes in children. Pediatr Diabetes 2006; 7:352-360.

24 Greenbaum CJ, Mandrup-Poulsen T, McGee PF, Battelino T, Haastert B, Ludvigsson J, Pozzilli P, Lachin JM, Kolb H; Type 1 Diabetes Trial Net Research Group, European C-Peptide Trial Study Group: Mixed-meal tolerance test versus glucagon stimulation test for the assessment of beta-cell function in therapeutic trials in type 1 diabetes. Diabetes Care 2008;31:1966-1971.

25 Wang L, Lovejoy NF, Faustman DL: Persistence of prolonged C-peptide production in type 1 diabetes as measured with an ultrasensitive C-peptide assay. Diabetes Care 2012;35: 465-470.

26 Besser RE, Shields BM, Casas R, Hattersley AT, Ludvigsson J: Lessons from the mixedmeal tolerance test: use of 90 -minute and fasting C-peptide in pediatric diabetes. Diabetes Care 2013;36:195-201.

27 Clarson C, Daneman D, Drash, et al: Residual beta cell function in children with T1DM: Reproducibility of testing and factors influenicing insulin secretory reserve. Diabetes Care 1987;10:33-38.

28 Besser RE, Ludvigsson J, Jones AG, McDonald TJ, Shields BM, Knight BA, Hattersley AT: Urine C-peptide creatinine ratio is a noninvasive alternative to the mixed-meal tolerance test in children and adults with type 1 diabetes. Diabetes Care 2011;34:607-609.

29 Yilmaz Agladioglu S, Sagsak E, Aycan Z: Urinary C-peptide/creatinine ratio can distinguish maturity-onset diabetes of the young from type 1 diabetes in children and adolescents: a single-center experience. Horm Res Paediatr 2015, Epub ahead of print.

30 Besser RE, Shepherd MH, McDonald TJ, Shields BM, Knight BA, Ellard S, Hattersley AT: Urinary C-peptide creatinine ratio is a practical outpatient tool for identifying hepatocyte nuclear factor 1-\{alpha\}/hepatocyte nuclear factor 4-\{alpha\} maturity-onset diabetes of the young from long-duration type 1 diabetes. Diabetes Care 2011;34:286-291.

31 Besser RE, Shields BM, Hammersley SE, Colclough K, McDonald TJ, Gray Z, et al: Home urine C-peptide creatinine ratio (UCPCR) testing can identify type 2 and MODY in pediatric diabetes. Pediatr Diabetes 2013;14: 181-188. 